sciendo Zagreb International Review of Economics \& Business, Vol. 22, Special Conference Issue, pp. 25-36, 2019 (C) 2019 Faculty of Economics and Business, University of Zagreb and De Gruyter Open All rights reserved. Printed in Croatia ISSN 1331-5609; UDC: $33+65$

DOI: 10.2478 /zireb-2019-0003

CONFERENCE PAPER

\title{
Dividend Policies and Business Groups: the Case of Croatia
}

\author{
Martina Sopta* \\ Mihaela Mikic * \\ Tin Horvatinovic *
}

\begin{abstract}
There are two competing hypothesizes on whether firms that are part of a business group should pay higher or lower dividends. Under one hypothesis, that can have different theoretical assumptions, firms that are a part of a business group should pay higher dividends. In contrast, if the pecking order hypothesis holds, firms that operate within a business group should pay lower dividends. The purpose of this paper is to examine the effect of group affiliation of Croatian firms, which are listed on the Zagreb Stock Exchange, on their propensity to pay dividends. Two panel data models were used in line with recent literature and the results of the study show some evidence that the pecking order theory was followed by Croatian firms. From this result the conclusion is that Croatian firms are more likely to pay dividends if they are not part of a business group.
\end{abstract}

Keywords: Business Group; Dividend Policy; Internal Capital Market; Pecking Order Theory

JEL Classification: G30, G35, L26

\section{Introduction}

The literature on the topic on dividend policies and payouts is very rich. What is meant by this statement is that there are vast number of theoretical models and empirical studies in this particular field of corporate finance. It can be said that the research on dividends started with the seminal work of Miller and Modigliani (1961). In that paper they claimed that under the conditions of the perfect market, rational behavior and perfect certainty dividend policy of firms is irrelevant in the sense that it cannot influence the firm value. From that moment on, there have been and prob-

\footnotetext{
* Martina Sopta, Mihaela Mikić and Tin Horvatinović are at Faculty of Economics and Business, University of Zagreb, Zagreb, Croatia.
} 
ably will still continue to be disputes and debates on the role that dividends play on many aspect of corporations. To further complicate the matter, there is a question does group affiliation matter to dividend payouts of firms. This is a very important question that is the center of this paper and one that we wish to answer on the sample of Croatian firms because there are reasons to think that when financial markets have frictions, internal and external capital markets are not substitutes (e.g. Stiglitz \& Weiss, 1981). There are additional postulates that need to be looked and analyzed before attempting to answer that question. To put it differently, another line of research in the financial and economics literature needs to be put alongside traditional corporate finance findings, and that is the internal capital markets field of firm analysis.

\section{Internal Capital Markets and Dividends}

Just as one can argue that the work of Miller and Modigliani (1961) started a wide interest in the subject of dividend policies, it can also be argued that the works of Alchian (1969) and Williamson (1975) made the internal capital markets an established research filed in the scientific literature. Both claim, in some sense, that the more the firm is diversified the more efficient it becomes. The consequence of a well-diversified firm is a potential of the firm to establish its own internal capital market, whereby internal capital market we mean capital allocation mechanism to various firms business segments (Peyer, 2002). Since the early lines of research on the topic of internal capital markets, there have been a great number of studies that have found mixed results with regards to the efficiency of internal capital markets. Several reasons were postulated to justify the hypothesis that internal capital markets are efficient. Diversification of business activities was already mentioned. The reduction of agency costs is one possible reason why internal capital markets of diversified firms could be more efficient than of those firms that do not have diversified business activities (Fluck \& Lynch, 1999). In addition to diversification, "winner-picking" is another explanation of the efficient internal market hypothesis. Stein (1997) by emphasizing the role of the corporate headquarters states that internal capital markets can add value to a corporation if funds are actively allocated to business segments in line with the expectation of their performance. Finally, synergies between business units were proposed as an explanation of internal capital market efficiency (Williamson, 1975). There is no clear and exact definition of synergy in the internal capital markets literature, but the underlying point is that capital allocation from one business segment to others is guided by the maximization of the value of business segments that the capital was transferred to.

On the other hand, some studies have found the opposite, meaning that internal capital markets are inefficient in allocating resources to profitable segments of 
the firm. Rajan, Servaes and Zingales (2000) showed that firms, when faced with increased opportunities, have made investments in inefficient investment projects. Additionally, Shin and Stulz (1998) point out that the shortage of cash flows by one segment can affect other segments investments regardless of the profitability of the mentioned investments. This line of research with regards to internal capital markets wouldn't be relevant for this paper, in other words the examination of business group dividend payouts, if it weren't for the fact that business groups do have their own internal capital markets (Samphantharak, 2006).

In light of the above presented information, there is potentially a connection between the existence of internal capital markets of business groups and dividend payouts. The influence of business group affiliation on dividend policies of corporations is not as widely studied as other influences on dividend payouts and as other aspects of internal capital markets, for example the question of internal capital market efficiency that was previously presented in this paper. Put it differently, there have been few papers that connect internal capital markets (business groups) and dividend policies of firms (e.g. Gopalan, Vikram \& Seru, 2014; Goldman \& Viswanath, 2017). Nevertheless, from the theories of an internal capital market it follows that managers will have capital from different segments of the corporation and they must make decisions regarding the use and allocation of that capital (Liebeskind, 2000). One of the ways managers could use the mentioned capital is to payout dividends. Just as was the case with the efficiency of internal capital markets, there are conflicting theories with regards to dividend payments of business groups. By conflicting theories we mean theories that start from different axioms and finish with different conclusions and predictions.

The pecking order theory was phrased by Myers (1984) and it states that the firm will prefer to use internally generated funds over external financial resources because using internally generated funds will send positive signals to investors. Even though acquiring debt could also be regarded as a positive signal, firms would firstly use retained earnings to finance their investment projects. High flotation costs of external sources of financing are the second reason why firms could follow this pattern of financing (Donaldson, 1961). This theory predicts that larger firms, which have developed internal capital markets, should pay lower dividends because they can more effectively finance their investments than smaller firms which do not have internal capital markets (Goldman \& Viswanath, 2017).

In contrast, market failure theory predicts that firms, that are part of a business group, should pay higher dividends. Market failure theory is a theory that explains the existence of internal capital markets from the perspective of information asymmetry and market imperfections. These factors were also used in the literature to explain dividend policies of corporations (Manos, Murinde \& Green, 2012). Assuming the market failure theory and the fact that firms that are part of a group are connect- 
ed through equity ownership (they can more easily transfer profits), group affiliated firms should have a higher propensity to payout dividends.

\section{Traditional Explanatory Variables of Dividend Policies}

In addition to group affiliation, several other factors have been proposed and tested to explain the propensity of firms to pay dividends. They can be grouped into internal and external factors. In this paper only internal factors were used to ensure the robustness of the panel data model. Since the purpose of this article is to test dividend payout policies by Croatian firms that belong to a business group, external factors were not chosen because they are mainly concerned with the country that the firm is established and operates. The internal factors that were used in the analysis are firm size, growth, leverage and profitability.

Firm size has been studied as an explanatory variable for corporate dividend policies and the results point to the conclusion that bigger firms pay more dividends. We say "point to the conclusion" in view that there have been studies, a minority, that have found this relationship to be negative. Gugler and Yurtoglu (2003) have shown, that among German firms, the size of the firm negatively affects dividend payouts. In contrast, Fama and French (2001) have found that, although firms in the United States of America in the 1970s and 1980s were overall less likely to pay dividends, smaller firms were less inclined to pay dividends. Similar results, regarding the effect of firm size and dividend policy, can be found in Al-Kuwari (2009) who sampled firms from Kuwait, Saudi Arabia, Oman, Qatar and Bahrain. These reason why most studies have found a positive effect is that larger firms have easier access to capital (Holder, Langrehr \& Hexter, 1998) and are less likely to go bankrupt (Titman \& Wessels, 1988).

Growth is another statistically significant determinant of dividend policies that can positively and negatively affect dividend payouts. The reason by this factor was found to be significant is that dividend payouts are directly linked to the size of earnings. In addition to the problem of the influence of growth on dividend payouts of firms, growth was defined and measured differently by authors of several studies which also adds ambiguity to the effect of growth on dividend policies. Growth can be defined as expected investment opportunities that can be measured as a ratio of market to book value of assets or market to book value of equity. Fama and French (2001) found this influence of growth on dividend policies to be negative, in other words to more the firm has investment opportunities it is statistically less likely to pay dividends. Aivazian, Booth and Cleary (2003) have found that this effect is of the opposite sign. Other authors define growth differently, they define growth as the annual growth of sales. Defining growth this way can, somewhat, reduce the ambiguity 
of the expected impact of growth on dividend policies. This approach of classifying growth was used in this paper. When firms are experiencing growth of sales they have to have financial resources to maintain higher levels of sales. If the assumption of higher cost of external financing holds, firms will use internally generated funds for investments. Because of higher capital expenditures firms will not pay dividends, in other words when firms have high growth of sales they will be less inclined to payout dividends. This model was first proposed and tested by Rozeff (1982) and since has had other empirical confirmation (e.g. Llyod, Jahera \& Page, 1985).

Leverage of firms can and was measured, in many studies, by different financial metrics but the overall conclusion that can be made is that the more the firms is leveraged it is less likely to pay dividends. There are two reasons for this conclusion. One is that higher leveraged firms have less flexibility in their investment decisions, in other words they will not distribute dividends to shareholders because of future debt obligations (Aivazian, Booth \& Cleary, 2003). The second reason is tied to the theoretical model of agency costs of free cash flows (Jensen, 1986). The model states that dividend payouts can reduce the agency costs of free cash flow because the management of firms cannot use it for value destroying purposes. This model has also been tested and has empirical support (Agrawal \& Jayaraman, 1994).

Profitability of firms can also explain the difference in their dividend policies. The reason why more profitable firms should pay more dividends is very intuitive in view of the nature of dividend payouts. Dividends are paid, mostly, from retained earnings so the more retained earnings (more profitable) a firm has the higher their potential is to payout dividends. There are numerous papers that found empirical evidence for this claim (e. g. Fama \& French, 2001; Aivazian, Booth \& Cleary, 2003)

\section{Data and Methodology}

The sample consists of firms that have issued securities on the Zagreb Stock Exchange and that are still listed at the time that the information from the firms was gathered, which was in the month of April 2018. There are a total of 92 firms in the sample, but not all firms that have listed securities on the Zagreb Stock Exchange were incorporated in the sample. We follow the common practice in the literature in this area and excluded from the sample financial firms, government owned firms and state bodies. The selected period was from 2006 to 2017 because the Zagreb Stock Exchange released annual reports only for that time interval so we could not find reports before 2006. Furthermore, some firms did not publish their financial reports for the year 2017 in the time that the information was collected for this article and some firms did not publish their financial reports for previous (early) years, for example 2006 and 2007. For these reasons the panel data is unbalanced. The ratio of 
dividend payments over earnings before interest, taxes, depreciation and amortization is the dependent variable in our models. Figure 1. shows how this ratio changed for all firms in our sample from 2006 to 2017. Croatian companies do not have stable dividend to earnings before interest, taxes, depreciation and amortization ratios. Furthermore, the values of the ratio are low reach the lowest value in 2006 and the highest in 2009. From this and form the fact that 47 of 91 companies have made at least one dividend payment in sample period (14 of the 47 have distributed dividends one or two times), a preliminary conclusion can be made that Croatian firms do not frequently and consistently make dividend payments. Why Croatian firms do not use dividends is beyond the scope of this paper.

Figure 1: Ratio of dividend payments over earnings before interest, taxes, depreciation and amortization

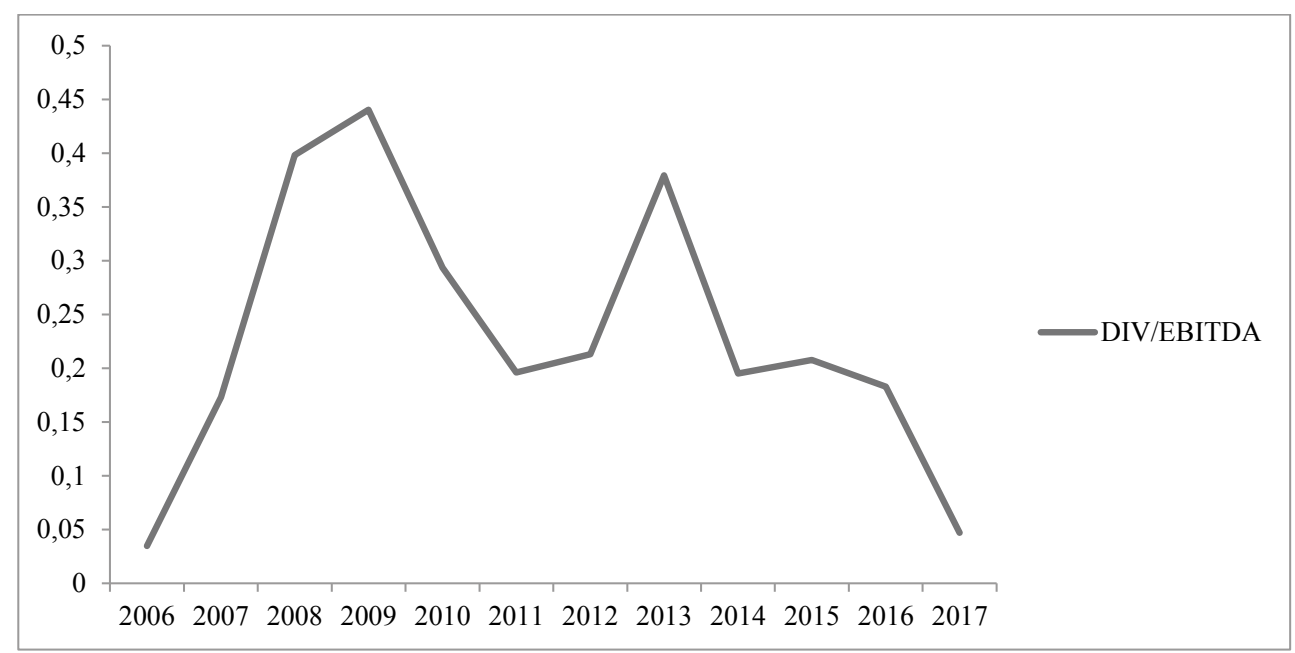

Source: Authors' own calculation, data from reports of corporations listed on the Zagreb Stock Exchange

Next we categorized firms whether or not they belong to a business group. The criterion for categorization is not established in the literature, or in other words the criterion varies from study to study. The criteria that was used in this research was the percentage of ownership, to be more specific if a firm has $51 \%$ ownership of another firm the latter firm is regarded as a group member. Since the data has a cross-sectional and time component, the appropriate statistical method is panel analysis. Even though many economic phenomena and relationships depend on their previous values, studies that have been carried out on this topic did not include lagged values in their models. In other words, most studies used static over dynamic panel data models when trying to test the relationship between group affiliation and dividend payments. Again, we 
followed the method that was predominantly used in the literature. In addition, some studies (e.g. Gopalan, Vikram \& Seru, 2014) used the Tobit model because the data is censored to ensure the validity of their results. The Tobit model was also used it this study. Furthermore, most studies used dummy variables as a constant term, but did not use dummy variables to consider the differences in the coefficients of the explanatory variables. We used both the additive and the multiplicative form of dummy variables to examine further relationships and for robustness checks.

The first step in the statistical analysis was to determine the appropriate model for our data. Since we assumed that the group affiliation was constant through the selected period, the fixed model was not the appropriate model. Nevertheless, a Hausman test was carried out and the results are displayed in table 1. From the results of the Hausman test, the null hypothesis is not rejected, we can conclude that the random effects model is more suitable for our dataset than the fixed effects model. The next test that was used was the Breusch and Pagan LM test for random effects on the basis on which we can determine whether to use the random effects model or the polled OLS model. The results of this test are also shown in table 1. We cannot reject the null hypothesis of the Breusch and Pagan LM test for random effects and therefore conclude that the polled OLS model should be used in our analysis.

Table 1: Results of the test for model selection

\begin{tabular}{|l|c|}
\hline Tests & Chi-Sq. Statistic \\
\hline Hausman test & 1.34 \\
& $(0.85)$ \\
\hline Breusch and Pagan LM test & 0.00 \\
& $(0.48)$ \\
\hline
\end{tabular}

Note: p-value in parenthesis.

Source: Authors' own calculations.

\section{Results}

The results of the polled OLS model are shown in table 2 and the results of the Tobit regression are shown in table 3. The variables in the tables are categorized as follows:

- Dividend payout: the ratio dividends paid by firm over its earnings before interest, taxes, depreciation and amortization

- Group: dummy variable that identifies a firm that is part of group

- Firm size: natural logarithm of the book value of total assets of the firm

- Growth: the percentage growth of sales

- Leverage: : the ratio of total book value of debt over its book value of total assets 
- Profitability: the ratio of earnings before interest, taxes, depreciation and amortization over its book value of total assets

- Group*Firm size: multiplicative term of group dummy variable and natural logarithm of the book value of total assets of the firm

- Group*Growth: multiplicative term of group dummy variable and the percentage growth of sales

- Group*Leverage: multiplicative term of group dummy variable and the ratio of total book value of debt over its book value of total assets

- Group*Profitability: multiplicative term of group dummy variable and the ratio of earnings before interest, taxes, depreciation and amortization over its book value of total assets

Table 2: Panel model with pooled OLS (dependent variable: Dividend payout)

\begin{tabular}{|l|c|c|c|c|c|}
\hline & $(1)$ & $(2)$ & $(3)$ & $(4)$ & $(5)$ \\
\hline \multirow{2}{*}{ Group } & $\begin{array}{c}-0.217 \\
(0.312)\end{array}$ & - & - & - & - \\
\hline \multirow{2}{*}{ Firm size } & 0.083 & 0.089 & 0.090 & 0.079 & 0.092 \\
& $(0.135)$ & $(0.134)$ & $(0.135)$ & $(0.135)$ & $(0.134)$ \\
\hline \multirow{2}{*}{ Growth } & -0.001 & -0.001 & -0.001 & -0.001 & -0.003 \\
& $(0.004)$ & $(0.004)$ & $(0.005)$ & $(0.004)$ & $(0.004)$ \\
\hline \multirow{2}{*}{ Leverage } & -0.067 & -0.068 & -0.058 & 0.194 & -0.056 \\
& $(0.262)$ & $(0.262)$ & $(0.262)$ & $(0.495)$ & $(0.262)$ \\
\hline \multirow{2}{*}{ Profitability } & 0.632 & 0.632 & 0.590 & 0.661 & 0.793 \\
$(1.163)$ & $(1.164)$ & $(1.200)$ & $(1.172)$ & $(2.171)$ \\
\hline \multirow{2}{*}{ Constant } & -1.619 & -1.747 & -1.895 & -1.721 & -1.922 \\
& $(2.744)$ & $(2.724)$ & $(2.723)$ & $(2.728)$ & $(2.717)$ \\
\hline \multirow{2}{*}{ Group*Firm size } & - & -0.010 & - & - & - \\
\hline \multirow{2}{*}{ Group* Growth } & - & - & -0.001 & - & - \\
\hline \multirow{2}{*}{ Group*Leverage } & - & - & - & -0.295 & - \\
\hline \multirow{2}{*}{ Group*Profitability } & - & - & - & - & -0.320 \\
\hline N & 835 & 835 & 835 & 835 & 835 \\
\hline
\end{tabular}

Note: Standard errors in parenthesis.

$* * *, * * *$ indicate significance at $1 \%, 5 \%$ and $10 \%$.

Source: Authors' own calculations. 
Table 3: Panel model with Tobit (dependent variable: Dividend payout)

\begin{tabular}{|c|c|c|c|c|c|}
\hline & (1) & (2) & (3) & (4) & (5) \\
\hline Group & $\begin{array}{c}-0.332^{* * * *} \\
(0.097)\end{array}$ & - & - & - & - \\
\hline Firm size & $\begin{array}{l}0.219^{* * * *} \\
(0.028)\end{array}$ & $\begin{array}{l}0.228^{* * * *} \\
(0.027)\end{array}$ & $\begin{array}{c}0.249^{* * * *} \\
(0.021)\end{array}$ & $\begin{array}{l}0.153^{* * *} \\
(0.035) \\
\end{array}$ & $\begin{array}{l}0.218^{* * *} \\
(0.021)\end{array}$ \\
\hline Growth & $\begin{array}{l}-0.048 \\
(0.036)\end{array}$ & $\begin{array}{l}-0.048 \\
(0.037)\end{array}$ & $\begin{array}{l}-0.030 \\
(0.068)\end{array}$ & $\begin{array}{l}-0.039 \\
(0.032)\end{array}$ & $\begin{array}{l}-0.055 \\
(0.038)\end{array}$ \\
\hline Leverage & $\begin{array}{c}-0.742^{* * *} \\
(0.140) \\
\end{array}$ & $\begin{array}{c}-0.743^{* * *} \\
(0.140) \\
\end{array}$ & $\begin{array}{c}-0.840^{* * * *} \\
(0.134) \\
\end{array}$ & $\begin{array}{c}-0.562^{* * * *} \\
(0.157) \\
\end{array}$ & $\begin{array}{c}-0.800^{* * * *} \\
(0.139) \\
\end{array}$ \\
\hline Profitability & $\begin{array}{l}1.409^{* * * *} \\
(0.300)\end{array}$ & $\begin{array}{l}1.437^{* * * *} \\
(0.299) \\
\end{array}$ & $\begin{array}{l}2.025^{* * *} \\
(0.282) \\
\end{array}$ & $\begin{array}{l}1.217^{* * *} \\
(0.294) \\
\end{array}$ & $\begin{array}{l}2.350^{* * * *} \\
(0.510)\end{array}$ \\
\hline Constant & $\begin{array}{c}-4.512^{* * * *} \\
(0.601) \\
\end{array}$ & $\begin{array}{l}-4.714^{* * * *} \\
(0.596) \\
\end{array}$ & $\begin{array}{c}-5.842^{* * * *} \\
(0.436) \\
\end{array}$ & $\begin{array}{c}-3.240^{* * * *} \\
(0.725)\end{array}$ & $\begin{array}{c}-5.167^{* * * *} \\
(0.441)\end{array}$ \\
\hline Group*Firm size & - & $\begin{array}{c}-0.015^{* * *} \\
(0.004) \\
\end{array}$ & - & - & - \\
\hline Group* Growth & - & - & $\begin{array}{l}-0.039 \\
(0.090)\end{array}$ & - & - \\
\hline Group $*$ Leverage & - & - & - & $\begin{array}{l}-0.083 \\
(0.176) \\
\end{array}$ & - \\
\hline Group*Profitability & - & - & - & - & $\begin{array}{l}-0.970^{*} \\
(0.522) \\
\end{array}$ \\
\hline $\mathrm{N}$ & 835 & 835 & 835 & 835 & 835 \\
\hline
\end{tabular}

Note: Standard errors in parenthesis.

$* * *, * *, *$ indicate significance at $1 \%, 5 \%$ and $10 \%$.

Source: Authors' own calculations.

The results of the importance of group affiliation on dividend payouts are mixed. With regards to the model 1 in table 2, which shows the results of the polled OLS with no multiplicative terms, we find no evidence that group affiliation affects dividend payouts. Furthermore, no multiplicative terms were found to be significant. These results, from the polled OLS model, imply that group membership does not have any effect on dividend payouts of the sampled firms in Croatia.

In contrast, the results in table 3 of the Tobit model show that group membership is a factor in explaining dividend payouts of firms. Group membership is statistically significant on all levels of significance. The sign of the coefficient is negative meaning that firms are less likely to payout dividends if they are part of a business group. In other words, there is reason to suppose that the pecking order theory holds for the sampled firms from which it follows that the sampled firms prefer to finance their investment projects with internally generated funds. In addition, two multiplicative terms were also found to be statistically significant. Group and firm size are significant on all levels of significance, while group and profitability was significant on 
$10 \%$ level of significance. This implies that effect of firm size and profitability, on the censored values of the dividend payouts indicator, was greater for firms that were not part of a business group.

\section{Conclusion}

Dividend policies and internal capital markets have been extensively studied from different aspects for many years and there is still an ongoing debate with regards to their capability to enhance firm value. While there have been many studies that looked at these firm components separately, there have been few studies that incorporated them in one model. Furthermore, the findings of these studies were not conclusive and have produced mixed results. What is meant by that statement is that there is no decisive evidence on whether group affiliated firms should pay higher dividends in comparison with firms that are not part of a business group. Two general theories have been proposed and empirically tested. Pecking order theory predicts that group affiliated firms should pay lower dividends, while the market failure theory predicts. The goal of this paper was to examine which of these theories, if any, holds for Croatian firms that listed on the Zagreb Stock Exchange. The key findings are that firms that are part of a business group pay lower dividends which is in accordance with the pecking order theory. However, the results vary dependent on the panel data that was used. Using the polled OLS model we found no evidence for the effect of group affiliation on dividend payouts. In contrast, using the Tobit model group affiliation and the size and profitability interactive terms were found to be significant. From this we can conclude that there is some evidence on the influence of group affiliation on dividend policies of Croatian firms. There are a few limitations in our study that future studies could take into account when doing further analysis on this topic. Firstly, different studies use different definitions of group membership but we define a firm as being part of a business group if it does not have the majority of its own equity ownership. The problem is that there is not settled definition of business groups and the results could vary by using different definitions of business groups. Secondly, we assume that group affiliation is time invariant and future studies could relax this assumption. Also future studies could look at dividend payouts more minutely, for example the difference between of dividend policies of foreign and non-foreign firms that are part of a business group or the effect that investments in business groups have on dividend payouts. 


\section{REFERENCES}

Agrawal, A. \& Jayaraman, N. (1994). The Dividend Policies of All-Equity Firms: A Direct Test of the Free Cash Flow Theory. Managerial and Decision Economics, 15(2), 139-148. DOI: 10.1002/ mde.4090150206.

Aivazian, V., Booth, L. \& Cleary, S. (2003). Do Emerging Market Firms Follow Different Dividend Policies From U.S. Firms? Journal of Financial Research, 26(3), 371-387. DOI: 10.1111/14756803.00064.

Alchian, A. (1969). Corporate management and property rights. In Manne, H. (Eds.), Economic policy and the regulation of corporate securities (pp. 337-360) American Enterprise Institute: Washington.

Al-Kuwari, D. (2009). Determinants of the Dividend Policy of Companies Listed on Emerging Stock Exchanges: The Case of the Gulf Cooperation Council (GCC) Countries. Global Economy \& Finance Journal, 2(2), 38-63.

Donaldson, G. (1961). Corporate Debt Capacity: A Study of Corporate Debt Policy and the Determination of Corporate Debt Capacity. Boston: Harvard University.

Fama, E. \& French, K. (2001). Disappearing dividends: Changing firms characteristics or low propensity to pay?. Journal of Finance Economics, 60(1), 3-43. DOI: 10.1016/s0304-405x(01)00038-1.

Fluck, Z. \& Lynch, A. (1999). Why Do Firms Merge and Then Divest? A Theory of Financial Synergy. The Journal of Business, 72(3), 319-346. DOI: 10.1086/209617.

Goldman, E. \& Viswanath, P. V. (2017). Internal Capital Markets, Forms of Intragroup Transfers, and Dividend Policy: Evidence from Indian Corporates. Journal of Financial Research, 40(4), 567-610. DOI: 10.1111/jfir.12135.

Gopalan, R., Nanda, V. \& Seru, A. (2014). Internal Capital Market and Dividend Policies: Evidence from Business Groups. Review of Financial Studies, 27(4), 1102-1142. DOI: 10.1093/rfs/hhu004.

Gugler, K. \& Yurtoglu, B. (2003). Corporate governance and dividend pay-out policy in Germany. European Economic Review, 47(4), 731-758. DOI: 10.1016/s0014-2921(02)00291-x.

Holder, M., Langrehr, F. \& Hexter, L. (1998). Dividend Policy Determinants: An Investigation of the Influences of Stakeholder Theory. Financial Management, 27(3), 73-82. DOI: 10.2307/3666276.

Jensen, M. (1986). Agency Costs of Free Cash Flow, Corporate Finance, and Takeovers. The American Economic Review, 76(2), 323-329. DOI: 10.2139/ssrn.99580.

Liebeslikind, J. P. (2000). Internal Capital Markets: Benefits, Costs and Organizational Arrangements. Organization Science, 11(1), 58-76. DOI: 10.1287/orsc.11.1.58.12568.

Lloyd, W., Jahera, J. \& Page, D. (1985). Agency costs and dividend payout ratios. The Financial Review, 20(3), 78-78. DOI: 10.1111/j.1540-6288.1985.tb00256.x.

Manos, R., Murinde, V. \& Green, C. (2012). Dividend policy and business groups: Evidence from Indian firms. International Review of Economics \& Finance, 21(1), 42-56. DOI: 10.1016/j. iref.2011.05.002.

Miller, M. \& Modigliani, F. (1961). Dividend Policy, Growth, and the Valuation of Shares. The Journal of Business, 34(4), 411-433. DOI: 10.1086/294442.

Myers, S. C. (1984). The Capital Structure Puzzle. Journal of Finance, 39(3), 574-592. DOI: $10.2307 / 2327916$.

Peyer, U. (2002). Internal and External Capital Markets. Retrieved January 12, 2018, from Social Science Research Network: https://ssrn.com. DOI: 10.2139/ssrn.309746

Rajan, R., Servaes, H. \& Zingales, L. (2000). The Cost of Diversity: The Diversification Discount and Inefficient Investment. Journal of Finance, 55(1), 35-80. DOI: 10.1111/0022-1082.00200.

Rozeff, M. (1982). Growth, beta and agency costs as determinants of dividend payout ratios. Journal of Financial Research, 5(3), 249-259. DOI: 10.1111/j.1475-6803.1982.tb00299.x. 
Samphantharak, K. (2006). Internal Capital Markets in Business Groups. Retrieved January 06, 2018, from Social Science Research Network: https://ssrn.com. DOI: 10.2139/ssrn.975562.

Shin, H. \& Stulz, R. (1998). Are Internal capital Markets Efficient?. The Quarterly Journal of Economics, 113(2), 531-552. DOI: 10.1162/003355398555676.

Stein, J. (1997). Internal Capital Markets and the Competition for Corporate Resources. The Journal of Finance, 52(1), 111-133. DOI: 10.2307/2329558.

Stiglitz, J. \& Weiss, A. (1981). Credit Rationing in Markets with Imperfect Information. The American Economic Review, 71(3), 393-410. DOI: 10.2307/1802787.

Titman, S. \& Wessels, R. (1988). The Determinants Of Capital Structure Choice. The Journal of Finance, 43(1), 1-19. DOI: 10.1111/j.1540-6261.1988.tb02585.x.

Williamson, O. (1975). Markets and Hierarchies: Analysis and Antitrust Implications. Free Press: New York. 